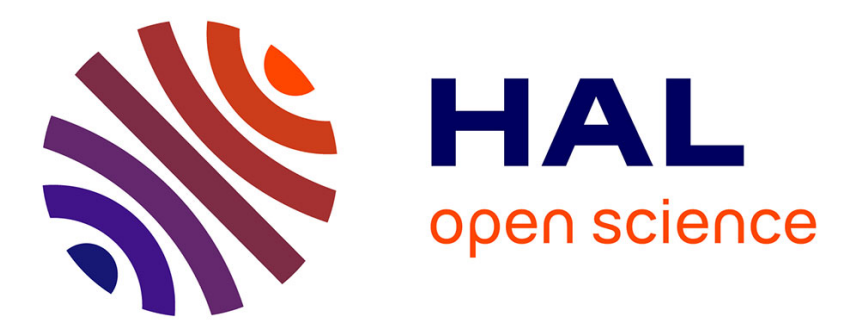

\title{
Environmental inequalities on the coast of north Charente-Maritime department in exposure to hazards
}

\author{
Nathalie Long, Pierre Cornut, Virginia Kolb
}

\section{To cite this version:}

Nathalie Long, Pierre Cornut, Virginia Kolb. Environmental inequalities on the coast of north Charente-Maritime department in exposure to hazards. ICE Coastal Management, Sep 2019, La Rochelle, France. halshs-02397549

\section{HAL Id: halshs-02397549 \\ https://shs.hal.science/halshs-02397549}

Submitted on 6 Dec 2019

HAL is a multi-disciplinary open access archive for the deposit and dissemination of scientific research documents, whether they are published or not. The documents may come from teaching and research institutions in France or abroad, or from public or private research centers.
L'archive ouverte pluridisciplinaire $\mathbf{H A L}$, est destinée au dépôt et à la diffusion de documents scientifiques de niveau recherche, publiés ou non, émanant des établissements d'enseignement et de recherche français ou étrangers, des laboratoires publics ou privés. 


\title{
Environmental inequalities on the coast of north Charente-Maritime department in exposure to hazards
}

\author{
Nathalie Long, UMR LIENSs, University of La Rochelle - CNRS, La Rochelle, \\ France \\ Pierre Cornut, Faculty of architecture and urbanism, University of Mons, Mons, \\ Belgique \\ Virginia Kolb, UMR LIENSs, University of La Rochelle - CNRS, La Rochelle, France
}

\begin{abstract}
700,000 ha of the French mainland coast are low-lying and concern 1.4 million people who are exposed to coastal hazards like marine submersion (MEDDE, 2012). In the last few years and since the Xynthia storm of February 2010, different adaptation strategies were developed and implemented to protect people and property: "Managed realignment", "hold the line" or "limited intervention" when adaptation of buildings or other infrastructures is achievable. The choice between one or the other strategy is mainly based on a cost-benefit analysis with less attention to social criteria. In the North of the CharenteMaritime department, the "hold the line" strategy is the most often chosen, sometimes mixed with relocation of houses.

Environmental inequalities are defined as social and intra- / inter-generational inequalities determined both through the quality and state of the environment and through the social structure (Pye et al., 2008; Deldreve, 2015). Coastal territories in France are attractive to live and work in but this brings inequalities. Because of the high price of properties, only high-level income classes can fully benefit from coastal amenities. In addition, particular social classes are more or less exposed to coastal hazards.

This paper highlights and questions some of these environmental inequalities in coastal and urban territories in France (specifically the urban community of La Rochelle, extended to the north up to the Charron municipality) and focuses upon the impact of adaptation strategies and of the insurance system. From a geo-statistical analysis, our results tend to balance the hypothesis that people who are the most disadvantaged are more exposed to hazards than the better-off. Similarly, the hypothesis that the betteroff have more access to coastal amenity is not obvious. Our study, however, shows other more clearcut results, related to political power, through the capacity to address public authorities and to obtain protection measures. From this case study, a discussion about the social consequences of the different strategies of adaptation will complete this analysis. The French insurance system, mainly based on costbenefit analysis, receives some scrutiny in relation to its role in maintaining or strengthening inequalities on the coast.
\end{abstract}

\section{Introduction}

Coastal areas are attractive spaces in terms of population and activity, despite exposure to coastal risks, such as a rise in the sea level or marine submersion. This trend toward 'coastalisation' of societies is expected to continue in the future on a global scale: the population density in coastal areas is currently higher than in non-coastal areas and most of the world's megacities are located in these zones (Neumann et al., 2015). Still on a global scale, Seto et al. (2011) showed that proximity to the coast was one of the factors explaining the urban sprawl in these coastal territories. In metropolitan France, nearly $40 \%$ of the population lives within $100 \mathrm{kms}$ of the coast, which represents nearly 24 million people (INSEE, 2008; UNEP, 2009). More specifically, 1.4 million people are directly exposed to the risk of submersion (MEDDE, 2012).

For several centuries, humans have focussed their efforts on conquering new maritime spaces to meet human needs. Now, there is an increased appreciation of the need to respond to extreme events and 
rising sea levels requires new choices to be made between protection and adaptation (Cooper \& Lemckert, 2012; Hino et al., 2017). To protect the populations and structural features (infrastructures, amenities, economic activities, etc.) which are exposed (Williams et al., 2018) to marine hazards, three major risk management strategies are currently adopted. Firstly, hard defences, such as seawalls or rock armour, permit action to be taken against the hazard itself; its cost over the long term and its impact on the coastal environment can be questioned but some coastlines, which are already highly urbanized, have no other choice. Secondly, unlike the first strategy, attenuation or mitigation aims to return coastlines to their natural functioning, so that they play their role as buffer and damping zones in respect of marine hazards. With this strategy, the risk is always present and the inhabitants simply have to live with it. Thirdly, relocation of structural and social features is returning formerly conquered territories to the sea, for example by de-polderization. This strategy is used in places when the cost of hard protection is higher than the cost of the features to be protected. The advantage of a strategic retreat is the increased resilience of coastal ecosystems. These three strategies do not impact populations and the coastline in the same way (Williams et al., 2018) and it is understood that this choice will result in 'losers' and 'winners' because it is primarily guided by a cost/benefit analysis (Cooper \& McKenna, 2008). Boda (2017) suggests that beyond economic and political choices, the social choice could also be taken into account and be considered as an alternative. This proposal is in line with the positions of Sen (1997) who puts forward an approach by capabilities, that is to say, the capacity of each individual and their fundamental freedom to lead their life as they wish in order to achieve genuine well-being.

Application of these adaptation strategies to coastal risks then brings into question their impacts on societies and on the environment in terms of justice. Several studies have shown that environmental policies have different impacts according to social categories: the poorest groups are often the most disadvantaged, the most socially vulnerable and the most exposed to coastal risks (Wallace, 2012, Velez et al., 2018). The Convention on Human Rights and Fundamental Freedoms stipulates that noone should be dispossessed of their assets (including property) unless there is a public interest, so it is a question of striking the right balance between public and private interests. The concept of social justice is defined as a fair distribution of costs and benefits across society (Cooper \& McKenna, 2008). Dobson (1999) associates this social justice with a goal of sustainable development of the environment, in other words, the maintenance of existing ecosystems, the two being strongly linked. Thus, during interventions on the coast, the main beneficiaries (such as property owners), the main payers (through local taxes), and the environmental impacts must all be identified. This is why, beyond an approach based on the sustainability of ecosystems and social justice, our chosen entry point is environmental inequalities that make it possible to analyse these inter- and intra-generational differences, partly determined by the quality and condition of the environment and partly by social structuring (Pye et al., 2008; Deldreve, 2015). This social-environmental relationship is fundamental in the case of coastal areas, because beyond being a risk area, the coastline is also a natural amenity. A natural amenity is defined by Shaeffer \& Dissart (2018) as "local attributes that provide a set of benefits to people (especially climatic, aesthetic and recreational benefits), [...] a contribution to the overall well-being or quality of life of the residents in a location, $[\ldots]$ as local characteristics generating attractiveness." Its environmental and aesthetic value is therefore recognized and impacts the populations present.

Indeed, its attractiveness has a strong influence on the price of land, forcing lower-income households to settle far from the coast, this spatial segregation even being reinforced near a centre city (Schaeffer et al., 2016; Frenkel \& Israel, 2018). This dual effect of socially differentiated vulnerability and accessibility makes the coastline a place of social and environmental inequalities, as shown by Kolb et al. (2014) for most of the coastline in metropolitan France.

To study this dual aspect of the coastline, both a risk area and a natural amenity, we have chosen to address the question via the inequalities of access to this amenity and exposure to coastal risks. The purpose of our study is to identify these environmental inequalities in coastal territories and to compare them with the socio-demographic profiles of residents in order to test the hypothesis whereby the most vulnerable populations are the most exposed to risk. This study was carried out on the specific case of the urban community of La Rochelle and the municipality of Charron, on the Atlantic coast, in metropolitan France. To meet these objectives, we will use spatial data for the coastal zone around La Rochelle, which is located in the north of the Charente-Maritime department. These data will then be processed by a principal component analysis (PCA) in order to identify relevant summary indicators and propose mapping of inequalities of access to natural amenities and risk exposures in the study area. Finally, these results will be presented and discussed with regard to coastal risk adaptation strategies chosen in these territories and the French insurance system. 


\section{Study area}

The study area is made up of the urban community of La Rochelle (UC La Rochelle) and the municipality of Charron, which borders it to the north (Figure 1). This study area corresponds to the territorial division used for implementation of the PAPIs (flood prevention action programmes) and, in particular, submersions. This area is a highly attractive and urbanised coastline. The UC La Rochelle is made up of 87 municipalities, but only the coastal municipalities and their neighbouring municipalities will be studied. This area, which numbers 25 municipalities, when Charron and its bordering municipalities are included, is dominated by the centre city of La Rochelle (about 75,000 inhabitants), where the majority of jobs, services and infrastructures are concentrated. The average population density of the UC La Rochelle is 415 inhab./sq.km., the highest of the department, but this conceals significant variability with nearly $50 \%$ of the population grouped in the city centre. The natural characteristics of the UC La Rochelle have an impact on the spatial distribution of the population and socio-demographic profiles. The coastal zone is marked by an ageing population, while the hinterland is witness to a certain demographic dynamism with the arrival of new families with young children.

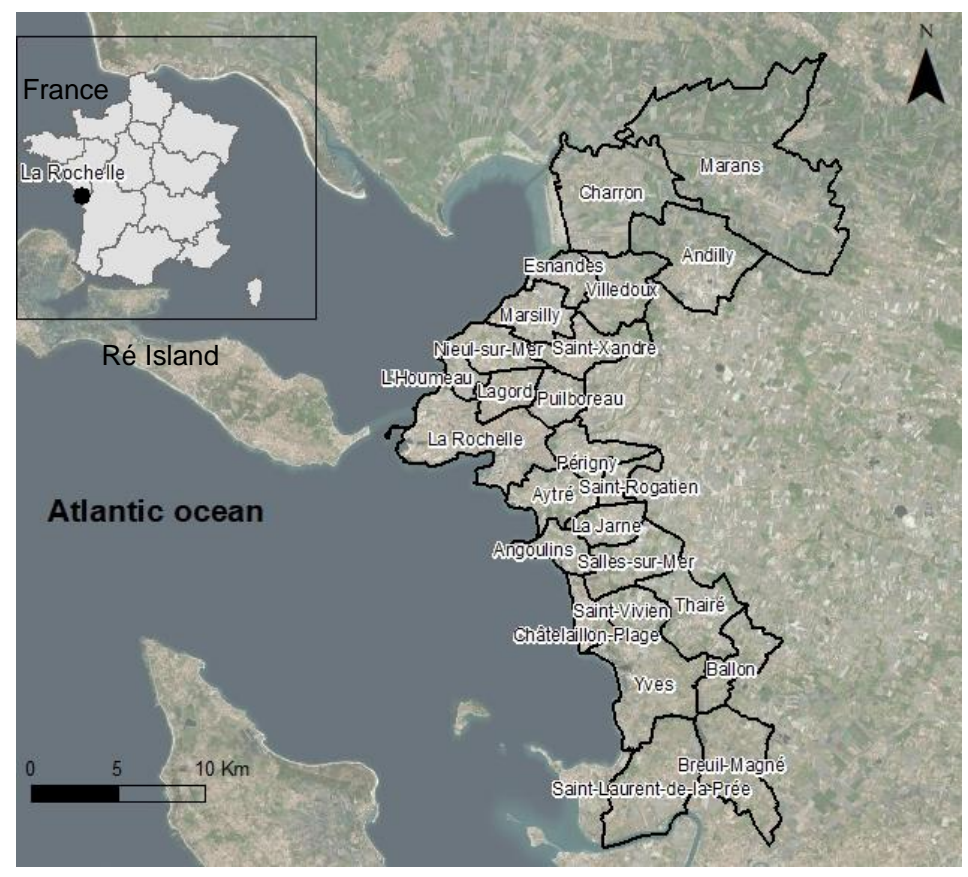

Figure 1: Location of the study area (black line: municipality limits)

Charron is a municipality bordering the UC La Rochelle and is located north of the latter, on the edge of the department. This is a mainly rural municipality, strongly influenced by the agricultural sector (production of cereals and livestock breeding) and mussel or oyster farming. It currently has fewer than 2,000 inhabitants, while occupying a strategic position between two major cities, La Rochelle and Luçon in Vendée. Its coastline is less attractive for tourism, being silty in nature.

From a geographical point of view, the coastline is varied throughout the study area: the coast north of La Rochelle is firstly silty and then subsequently dominated by cliffs on the city's edge, while south of the city centre, the coast is somewhat sandy (naturally or artificially) or pebbled. It is therefore south of La Rochelle that the seaside resorts of Chatelaillon-Plage and Fouras can be found. Near the coast, the pressure on land is therefore high and diminishes as you move further inland. These territories were hit hard by the Xynthia storm in February 2010. Significant material damage and loss of life occurred. Following this event, risk prevention plans were put back on the agenda and led to the deployment of various coastal risk management strategies. The construction of seawalls and the demolition of buildings and dwellings were the main strategies applied to this study area. 


\section{Data and methods}

\section{Data}

In order to define the two types of inequalities, we decided to synthetize different spatial information (i.e. a grid of variables for a set of spatial units) into three main indicators: access to natural amenities, exposure to risk, and socio-economic profiles. This method allows to establish a relationship between characteristics of a territory and population profiles.

In order to define a natural amenity indicator, we chose to use variables that provide information on the definition and characteristics of these natural spaces. Protected areas, spaces corresponding to green and blue belts, undeveloped areas and natural diversity of land occupation have been identified. More specifically in coastal areas, the coastline and beach presence have been identified in order to subsequently calculate a distance to these spaces (Table 1).

Table 1: Variables contributing to the natural amenity indicator

\begin{tabular}{|l|c|c|}
\hline Variables & Data source & $\begin{array}{c}\text { Date of } \\
\text { the data }\end{array}$ \\
\hline $\begin{array}{l}\text { Protected area }(5 \text { types of space: ZNIEFF* } \\
\text { and 2, SRCE*, ZICO*, APPB* }) \text { and natural } \\
\text { reserve area }\end{array}$ & DREAL17 & 2013 \\
\hline $\begin{array}{l}\text { Natural diversity of land occupation } \\
\text { (Simpson's index) }\end{array}$ & Urban Atlas & 2012 \\
\hline Area of green spaces & BD TOPO IGN & 2011 \\
\hline Area in the green belt & $\begin{array}{c}\text { Ecological coherence } \\
\text { scheme }\end{array}$ & 2015 \\
\hline Area in the blue belt & $\begin{array}{c}\text { Ecological coherence } \\
\text { scheme }\end{array}$ & 2015 \\
\hline Distance to the beach $(\mathrm{m})$ & DDASS & 2014 \\
\hline Water surface in & BD TOPO IGN & 2011 \\
\hline Unbuilt area & URBAN ATLAS & 2012 \\
\hline Distance to the coast $(\mathrm{m})$ & BD TOPO IGN & 2011 \\
\hline
\end{tabular}

\footnotetext{
* ZNIEFF: Natural area of fauna and flora ecological interest, SRCE: Regional ecological coherence scheme, ZICO: Important area for bird conservation, APPB: Prefectural order of biotope protection
}

Risk exposure indicator is composed of areas exposed to or concerned by a natural hazard; the risks due to anthropogenic activities have also been taken into account (Table 2).

Table 2: Variables contributing to the risk exposure indicator

\begin{tabular}{|c|c|c|}
\hline Variables & $\begin{array}{c}\text { Data } \\
\text { source }\end{array}$ & $\begin{array}{c}\text { Date of } \\
\text { the data }\end{array}$ \\
\hline Area exposed to shrinkage and swelling of clay & BRGM & 2003 \\
\hline Area exposed to groundwater lift & BRGM & 2011 \\
\hline Area exposed to submersion & DDTM17 & 2014 \\
\hline Area exposed to erosion & DDTM17 & 2009 \\
\hline Area exposed to floods & DDTM17 & 2009 \\
\hline SEVESO & DREAL & 2017 \\
\hline Sites with polluted soils & $\begin{array}{c}\text { BASOL } \\
\text { database }\end{array}$ & 2017 \\
\hline
\end{tabular}

\footnotetext{
${ }^{* *}$ European directive about dangerous substances (manufacture, storage, etc)
}

Finally, the socio-demographic indicator was defined based on variables relating to the income level, the family and household situation, the age groups, their type of residence in collective and/or social housing, the professional situation (unemployed, employment stability) and the level of education and training (Table 3). 
Table 3: Variables contributing to the socio-demographic profile indicator

\begin{tabular}{|c|c|c|}
\hline Variables & $\begin{array}{c}\text { Data } \\
\text { source }\end{array}$ & $\begin{array}{c}\text { Date of the } \\
\text { data }\end{array}$ \\
\hline Share of one-person households & INSEE & 2013 \\
\hline Share of one-parent family & INSEE & 2013 \\
\hline Share of people aged 0 to 17, 18 to 24, 25 to 64 & INSEE & 2013 \\
\hline Share of people aged over 65 & INSEE & 2013 \\
\hline Share of low-income households & INSEE & 2013 \\
\hline Share of households residing in apartment blocks & INSEE & 2013 \\
\hline $\begin{array}{c}\text { Share of owner households } \\
\text { temping work (precarious jobs) }\end{array}$ & INSEE & 2013 \\
\hline $\begin{array}{c}\text { Share of people aged 15 and over, out of school and } \\
\text { without any qualifications }\end{array}$ & INSEE & 2013 \\
\hline $\begin{array}{c}\text { Share of the unemployed } \\
\text { INSEE }\end{array}$ & 2013 \\
\hline $\begin{array}{l}\text { Shaple on fixed-term contracts or doing } \\
\text { INSEE }\end{array}$ & 2013 \\
\hline
\end{tabular}

\section{Methods}

\section{Data preparation}

To build an indicator, it is necessary to have all the variables on the same spatial scale, and for the same reference spatial unit (RSU), like a grid-cell. Most of the variables listed above are of the surface type, but do not correspond geographically to the same spatial unit. We chose to use the most detailed reference spatial unit possible in order to preserve the maximum precision for this analysis of territories. This RSU corresponds to the grid-cell reference used by INSEE (National Institute of Statistic and Economical Studies). The grid is composed of $200 \mathrm{~m} \times 200 \mathrm{~m}$ cells, covering the study area. Under a geographic information system (GIS, ArcGIS 10.6, ESRI), we transposed all areal variables to the scale of this grid reference, computing the percentage of surface or the number of sites, included in each cell.

Some variables required additional calculations. The Simpson index was calculated within each cell, according to the type of land occupation and use (5 different types of agricultural land, forests, prairies, grasslands on open spaces with little or no vegetation, wetlands, water areas) present in each grid. Calculation of distances to the coastline and beaches were made under GIS by means of a buffer calculation. Based on these amenities, buffers of $200 \mathrm{~m}, 400 \mathrm{~m}, 600 \mathrm{~m}, 800 \mathrm{~m}, 1,000 \mathrm{~m}, 2,500 \mathrm{~m}, 5,000 \mathrm{~m}$ and $10,000 \mathrm{~m}$ were calculated and the values attributed to the grid-cell by a spatial join.

\section{Statistical methods}

In order to highlight the spatial variability of the studied territory in terms of natural amenities, risk exposure and the socio-demographic profiles of the inhabitants, we used principal component analysis (PCA) on XLStat software. A PCA is a geostatistical method allowing analysis of a set of variables and spatialisation of the results, which permits discretization of the territory. PCA is a multivariate statistical method that consists of transforming variables linked together into new variables uncorrelated from each other. These new variables are called "main components" or axes and each component explains some of the information. This method reduces the number of variables and independent axes best explain the variance of the data. This method was used to calculate each of the indicators. It includes a standardization of the data beforehand in order to avoid size effects between the variables.

As a result, we obtain as many components as there are variables, but only the first two components are kept for the analysis, since the percentage of information explained by the following components is not significant (Kaiser criterion). The quite subtle difficulty then is to understand the 'meaning' of each component, which is done by looking at the positive and negative correlations between one component on the one hand, and all the variables on the other hand. When the component 'meaning' is established, then all spatial units, here the INSEE grid-cell, are categorized according to this 'meaning'.

For example, the first PCA computed from variables presented in Table 1 produces a first component that synthetizes the presence of protected natural areas (high positive correlation with the concerned variables) and thus can be considered as the synthetic indicator showing the spatial distribution of the natural amenities on the studied area. 


\section{Results}

\section{Inequalities of access to natural amenities}

The purpose of the natural amenity indicator is to define the environmental quality and naturalness of the spaces and, in particular, to position the coastal amenity in relation to the other natural amenities present in the study area. Only variables whose contribution is greater than the average contribution (i.e. $8.33 \%$ ) are selected for this analysis (Table 4). The model explains almost $45 \%$ of the cumulative variance.

Table 4: Correlation of the variables with the first two components of the PCA for the natural amenity indicator (the values in grey are non-significant)

\begin{tabular}{|c|c|c|}
\hline \multirow{2}{*}{ Variables } & \multicolumn{2}{|c|}{ Correlation coefficient } \\
\cline { 2 - 3 } & Component 1 & Component 2 \\
\hline \% of protected area (ZNIEFF1) & 0.77 & -0.25 \\
\hline \% of protected area (ZNIEFF2) & 0.82 & 0.19 \\
\hline \% of protected area (ZICO) & 0.80 & -0.13 \\
\hline \% of protected area (APPB) & 0.55 & 0.12 \\
\hline \% of protected area (SRCE) & 0.77 & -0.35 \\
\hline \% of natural reserve area & 0.08 & -0.22 \\
\hline \% of unbuilt area & 0.35 & 0.10 \\
\hline \% of water surface & 0.39 & 0.58 \\
\hline Distance to the coast & 0.76 & -0.00 \\
\hline Distance to a beach & -0.10 & 0.83 \\
\hline
\end{tabular}

This first component highlights the protected areas in the territory (Table 4). When looking at the mapped scores (Figure 4a), these areas (zones in ZNIEF, ZICO and SRCE) are found in spaces strongly influenced by nature or even agriculture, like in the municipalities of Charron and Marans, and in the South, Saint Laurent de la Prée and Yves. In contrast, the city of La Rochelle and its outer ring of suburbs as well as agricultural areas affected by peri-urban sprawl, appear as disadvantaged areas in terms of environmental quality.

The component 2 shows another zoning of the territory, which is only significantly structured by variables: unbuilt areas and the coast/ beach distance (Table 4). On this component, distance to the coast is highlighted, with the purely agricultural areas far from the coast (Figure 4b). Regarding the variables representing the coastal amenity, they show the coast accessibility of the territory.

\section{Inequalities of risk exposure}

This indicator of exposure to anthropogenic and natural hazards makes possible to highlight the most disadvantaged areas in terms of risks exposure. Similarly, only variables whose contribution is greater than the average of the contributions (i.e. 14.3\%) were used (Table 5). The model explains almost $41 \%$ of the cumulative variance.

Table 5: Correlation of the variables with the first two components of the PCA for the risk exposure indicator (the values in grey are non-significant)

\begin{tabular}{|l|c|c|}
\hline \multicolumn{1}{|c|}{ Variables } & \multicolumn{2}{c|}{ Correlation coefficient } \\
\cline { 2 - 3 } & \multicolumn{2}{c|}{ Component 1 } \\
\hline$\%$ of area exposed to submersion & 0.60 & -0.17 \\
\hline$\%$ of area exposed to erosion & -0.22 & -0.31 \\
\hline$\%$ of area exposed\% to floods & 0.52 & 0.27 \\
\hline$\%$ of area exposed to groundwater lift & 0.60 & 0.11 \\
\hline$\%$ of area exposed to clay shrinkage and swelling & 0.81 & 0.03 \\
\hline
\end{tabular}




\begin{tabular}{|l|c|c|}
\hline SEVESO sites & -0.19 & 0.68 \\
\hline Sites with polluted soils & -0.10 & 0.66 \\
\hline
\end{tabular}

For the first component, exposure to erosion risk and the presence of polluted and SEVESO sites are not significant (Table 5). The component synthetizes the other natural risks and the mapped scores (Figure 4c) show areas affected by clay shrinkage and swelling located in the north-eastern part of the study area, a predominantly agricultural zone. The town of Charron, the city centre and the south of the city centre of La Rochelle, and all along the lower coast of the UC La Rochelle are also concerned by hazards (submersion, flood and groundwater lift). North of La Rochelle, the coast is dominated by cliffs and is therefore not concerned by the risk of submersion all the way to the municipality of Esnandes.

Exposure to the industrial risk structures the second component and concerns La Rochelle and the eastern municipalities. They are opposed to areas concerned by erosion hazard (Figure 4d).

\section{Social profiles of the inhabitants}

The third indicator concerns the socio-demographic profiles of the inhabitants, described according to the level of educational achievement, the type and status of residents, the age group, employment stability and the level of income. Similarly, only variables whose contribution is greater than the average of the contributions (i.e. $8.3 \%$ ) were used (Table 6).The model explains almost $53 \%$ of the cumulative variance.

\section{Table 6: Correlation of the variables with the first two components of the PCA for the social profile indicator (the values in grey are non-significant)}

\begin{tabular}{|c|c|c|}
\hline \multirow{2}{*}{ Variables } & \multirow{2}{*}{$\begin{array}{c}\text { Correlation } \\
\text { Component } 1\end{array}$} & \multirow{2}{*}{$\begin{array}{l}\text { coefficient } \\
\text { Component } 2\end{array}$} \\
\hline & & \\
\hline Share of one-person households & 0.70 & 0.21 \\
\hline Share of one-parent family & 0.79 & 0.07 \\
\hline Share of people aged 0 to 17 & -0.22 & -0.64 \\
\hline Share of people aged 18 to 24 , & 0.27 & -0.15 \\
\hline Share of people aged 25 to 64 & -0.10 & -0.60 \\
\hline Share of people aged over 65 & 0.13 & 0.96 \\
\hline Share of low-income households & 0.56 & -0.37 \\
\hline Share of households residing in apartment blocks & 0.81 & -0.08 \\
\hline Share of owner households & -0.75 & 0.34 \\
\hline Share of people on fixed-term contracts or doing temping work (precarious jobs) & 0.83 & 0.03 \\
\hline Share of people aged 15 and over, out of school and without any qualifications & 0.46 & 0.09 \\
\hline Share of the unemployed & 0.81 & -0.05 \\
\hline
\end{tabular}

Socio-demographic profiles are discretized on component 1 (Table 6) in two groups: the first social profile is defined by composition of the household, their place of residence (apartment block) and their precariousness in terms of employment (fixed-term contract, temping, unemployment); The second social profile is defined by the variable representing the percentage of owner households. The first social profile may appear more vulnerable socially than the second one. Therefore, in Figure 4e, the most vulnerable households are located in the hyper-centre of La Rochelle and in its most disadvantaged neighbourhoods such as those of Mireuil, La Pallice and Villeuneuve-les-salines. Outside La Rochelle and Aytré, the socio-demographic profiles are influenced by the share of owner households, what implies a social category that is less vulnerable than the first and concerns all the other municipalities.

On component 2 (Table 6), the age structure of the population is highlighted: the youngest populations and the 24- 64 years age population is viewed against the population representing the retired, the oldest people. It is difficult to identify structuring of the space (Figure 4f). Apart from Marans, which also has a rather non-significant representation on this dimension, we identify the suburban-type municipalities, hosting households with children, which is in contrast to certain neighbourhoods of La Rochelle such as La Genette (west of the hyper centre), the municipality of Lagord and the municipality of ChâtelaillonPlage in the south, characterised by an older population. 

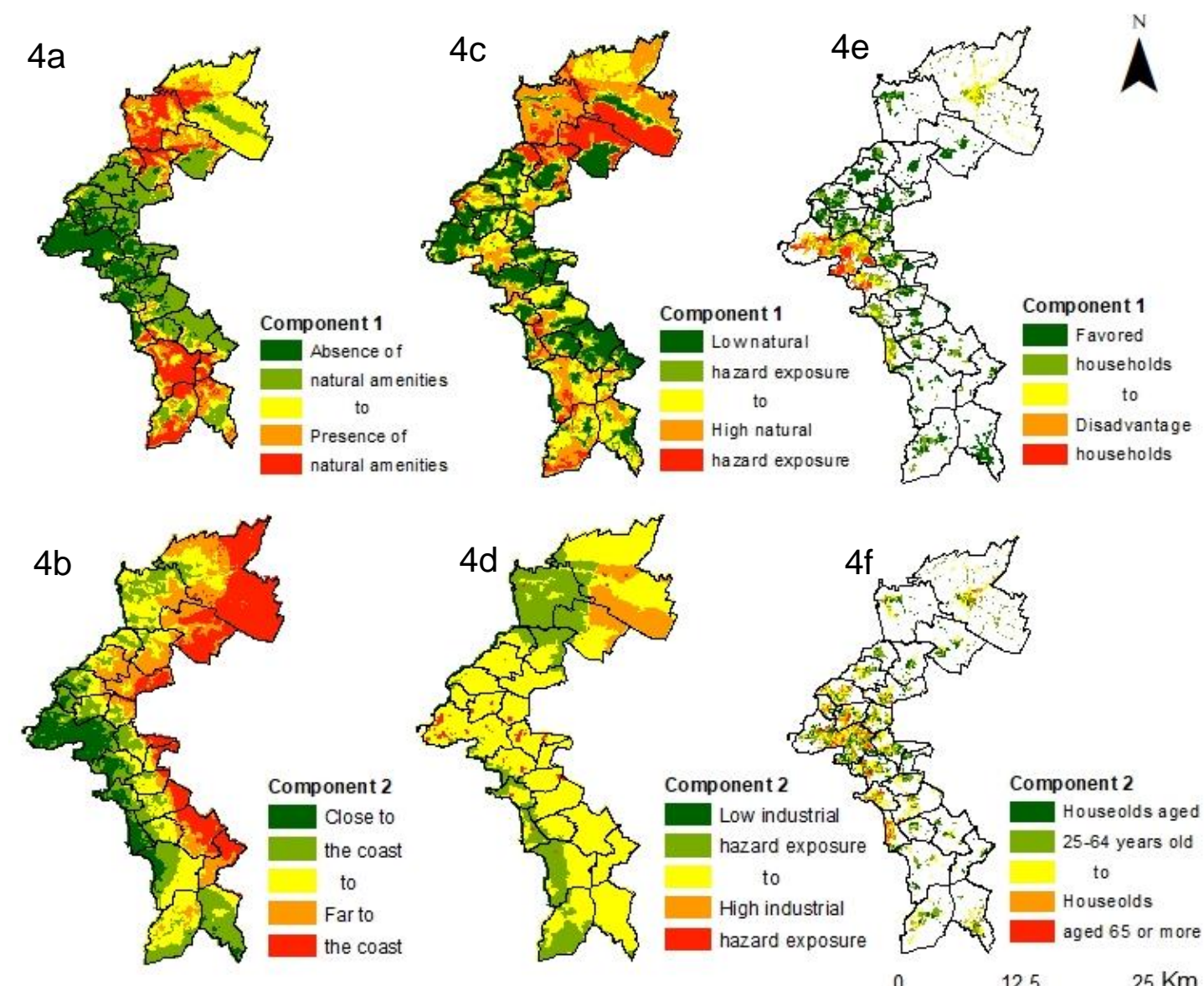

Houseolds aged 25-64 years old to Houseolds aged 65 or more

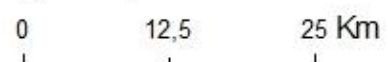

Figure 4: Mapping of the results of the PCA on the study area: natural amenity indicator (Component 1: 4a, Component 2: 4b), risk exposure indicator (Component 1: 4c, Component 2: 4d) and the socio profile of the inhabitants (Component 1:4e, Component 2: 4f). The black lines draw the limits of the municipalities.

\section{Discussion}

The first two indicators made it possible to highlight a certain discretization of the studied space, according to their environmental quality and exposure to risks. It is now necessary to cross-reference this information with the two main socio-demographic profiles identified: the most vulnerable classes and the most affluent classes and so test the hypothesis that the most vulnerable classes have less access to natural amenities and are more exposed to risks. We will see that the results are not as clear cut.

Regarding the accessibility of natural amenities, such as protected areas, the majority of the most vulnerable households in the municipality of La Rochelle are some way distant from these areas, mainly at the northern and southern ends of the study area. On the other hand, the most affluent classes are located between the city of La Rochelle and these zones of protected areas, which can be interpreted as a more favourable geographical location. This makes it possible to benefit from both natural amenities and urban amenities. On the other hand, the coastline seems equally accessible to both social classes, their spatial distribution not following this gradient of distance from the coast.

For risk exposure, we note that the most vulnerable households are indeed close to industrial sites or polluted sites in the western part of La Rochelle. They are also subject to the risk of submersion in the hyper-centre of La Rochelle. However, the more affluent classes are also subject to the risk of submersion in the municipalities of Angoulins, L'Houmeau and Charron. 
The two hypothesis are not demonstrated by this spatial analysis, except the affluent classes which are close to the natural amenity. However, the coastal adaptation strategies increase the environmental inequalities. During the Xynthia storm in February 2010, a significant part of the territory was impacted by submersion. Following this extreme event, coastal adaptation strategies were implemented through the PAPIs (flood prevention action programmes). Two strategies were mainly deployed: hard defences (seawall) and relocation of homes and businesses. Today, most of the lower coast of the study area with structural and population features is protected by a seawall. However, it can be noted, for example, that the municipality of Charron was the last to obtain the authorization to build the seawall in the north of the municipality, 8 years after the natural disaster. This difference in timeframes has been experienced as unfair by the people living in Charron and highlights unequal treatment of territories, which should be viewed alongside the capacity, which is just as inequal, to challenge the public authorities. The cost/benefit analysis suggested protecting the municipalities like La Rochelle and Chatelaillon-Plage, a seaside resort, where the land prices are higher than in Charron.

The decision to define "zones of solidarity" (areas exposed to submersion and therefore unbuildable after Xynthia storm, houses included in these areas were destroyed) has also been experienced as unequal. These decisions led to the demolition of many houses in the area, including nearly 180 in Charron, mainly the urban front line, facing the sea. The town of Aytré, south of La Rochelle, was also impacted. These decisions were made in the immediate aftermath of the natural disaster and were almost imposed upon the population, essentially based on economic criteria. The know-how and knowledge of people and their capabilities could have played an important role here and avoided situations of conflict between the public authorities and the local population but also significant trauma for those who were relocated and for those who remained. Several studies have thus demonstrated the need for consultation with the population in risk management decisions, while also showing the benefits for the environment (Touili et al., 2014; Rulleau et al., 2016; Sanchez-Arcilla et al., 2016; Hino, 2017).

Finally, although most of the territory is now protected by seawalls, this strategy has had a cost, borne by all French citizens holding insurance policies. In fact, in France, a system based on solidarity makes it possible to compensate those who are victims of natural disasters in particular. A levy is made automatically on each insurance policy, which goes to the 'Barnier fund', used to finance, among other things, coastal adaptation strategies. However, this system can be questioned and can appear somewhat unequal between households. We might hypothesise than this insurance system maintains a certain part of the population close to the coastline, while another part, due to lack of sufficient income, can only choose to reside further inland. Thus, if inequalities are not obvious by the statistical analysis carried out here, a qualitative approach could highlight feelings and perceptions of inhabitants about insurance system and coastal adaptation strategies.

\section{Conclusion}

Almost 10 years after the Xynthia storm, one might imagine that the populations of the UC La Rochelle and Charron are protected and that the coastline has also been safeguarded. To study these two aspects, an approach based on environmental inequalities seemed to us to be useful for studying the variability of the territory in its different dimensions on the one hand and the distribution of social inequalities on the other.

In the case of the north of Charente-Maritime, it is difficult to verify the hypotheses according to which the most vulnerable populations are most at risk or that the most affluent populations are mostly near the coast. The "coastal" effect is not systematic and is certainly associated with the effects of the coastal centre city in the distribution of the different social classes in the territory. However, on the scale of the municipalities, what emerges are inequalities in the treatment of territories, especially in the choice of areas for demolition or the building of defence structures.

Finally, at the national level, it is the solidarity-based insurance system that is being brought into question, by suggesting that this system favours the maintenance of the population on the coastal zone, exposed to coastal hazards. The sustainability of such a system can be questioned here in a context of global changes but also from a social angle with a decline in social cohesion. 


\section{References}

Boda C.S. (2018) From economic choice to social choice in coastal management: a critical assessment of the use of cost-benefit analysis in the evaluation of an erosion control project in Flager County, Florida, U.S.A., Ocean and coastal management, Vol 162, pp 85-99, Elsevier, Amsterdam.

Brown S, Nicholls R, Woodroffe C, Hanson S, Hinkel J, Kebede AS, et al. Sea-Level Rise Impacts and Responses: A Global Perspective. In: Finkl CW, editor. Coastal Hazards. Netherlands: Springer;2013. pp. 117-149.

Cooper JAG \& C Lemckert (2012) Extreme sea-level rise and adaptation options for coastal resort cities: a qualitative assessment from the Gold Coast, Australia, Ocean and coastal management, Vol 64, pp 1-14, Elsevier, Amsterdam.

Deldreve V (2015) Pour une sociologie des inégalités environnementales, Collection Ecopolis Vol 24, Peter Lang, Bruxelles.

Dobson A (1999) Fairness and futurity: essays on environmental sustainability and social justice, Oxford University Press, 344p.

Frenkel A. \& E. Israel (2018) Spatial inequality in the context of city-suburb cleavages - Enlarging the framework of well-being and social inequality, Landscape and urban planning, Vol 177, pp 328339.

Hino M, CB Field, KJ Mach (2017) Managed retreat as a response to natural hazard risk, Nature climate change, DOI: 10.1038/NCLIMATE3252, Springer.

INSEE 2008, https://www.insee.fr/fr/statistiques/1280767

Kolb V., N. Long, P. Marty (2014) Is the coast a vector of socio-environmental inequalities in coastal urban areas?, Proceeding of the CUl'14 /contemporary urban issues conference : Rethinking the informality, 13-15 Novembre 2014, Ed: AyŞe Güngör, Istanbul, Turquie, pp 236-251. ISBN : 978-605-5120-91-7.

Ministère de l'Écologie, du Développement durable et de l'Énergie (MEDDE), 2012. Stratégie nationale de gestion intégrée du trait de côte - Vers la relocalisation des activités et des biens, 19p, [En ligne] URL : http://www.developpement-durable.gouv.fr/Strategie-nationale-de-gestion.html.

Neumann B, Vafeidis AT, Zimmermann J,Nicholls RJ (2015) Future Coastal Population Growthand Exposure to Sea-Level Rise and Coastal Flooding - A Global Assessment. PLoS ONE 10(3):e0118571. doi:10.1371/journal.pone.0118571

Pye S, I Skinner, N Meyer-Ohlendorf, A Leipprand, K Lucas, R. Salmons (2008) Addressing the social dimensions of environmental policy $-A$ study on the linkages between environmental and social sustainability in Europe, European Commission, Directorate-General "Employment, Social Affairs and Equal Opportunities", 50p

Rulleau B., H Rey-Valette, V. Clément (2015) Impact of justice and solidarity variables on the acceptability of managed realignment, Climate policy, online, DOI: 10.1080/14693062.2015.1119097, Taylor \& Francis.

Sanchez-Arcilla A, M Garcia-Leon, V Gracia, R Devoy (2016) Managing coastal environments under climate change: pathways to adaptation, Science of the total environment, Vol 572, pp 13361352, Elsevier.

Schaeffer Y, D Cremer-Schulte, C Tartiu, M Tivadar (2016) Natural amenity-driven segregation: evidence from location choices in French metropolitan areas, Ecological Economics, Vol 130, pp 37-52, Elsevier, Amsterdam.

Schaeffer Y \& Dissart JC (2018) Natural and Environmental Amenities: A Review of Definitions, Measures and Issues, Ecological Economics, Vol 146, pp 475-496, Elsevier, Amsterdam.

Sen A. (1997) Editorial: Human capital and human capability, World development, Vol 25, pp 19591961, Elsevier, Great Britain.

Touili N, J Baztan, JP Vanderlinden, IO Kane, P Diaz-Simal, L Pietrantoni (2014) Public perception of engineering-based coastal flooding and erosion risk mitigation options: lessons from three European coastal settings, Coastal engineering, Vol 87, pp 205-209, Elsevier, Amsterdam.

UNEP, 2009, http://geodata.grid.unep.ch/results.php

Velez JMM, SB Garcia, AE Tenorio (2018) Policies in coastal wetlands: key challenges, Environmental science and policy, Vol 88, pp72-82, Elsevier, Amsterdam.

Wallace D.J. (2012) Policy and management hazards along the Upper Texas coast, Ocean and coastal management, Vol 59, pp77-82, Elsevier, Amsterdam.

Williams AT, Rangel-Buitragoc N, Pranzinid E, Anfuso G (2018) The management of coastal erosion, Ocean and coastal management, Vol 156, pp 4-20, Elsevier, Amsterdam. 